\title{
Synthesis, Characterization, Electrochemistry, and Spectroscopic Properties of Some Anthracenyl Functionalized Phthalocyanine Complexes of Ruthenium(II)
}

\author{
Adewale O. Adeloye and Peter A. Ajibade \\ Department of Chemistry, Faculty of Science and Agriculture, University of Fort Hare, P.M.B. X1314, Alice 5700, South Africa \\ Correspondence should be addressed to Peter A. Ajibade; pajibade@ufh.ac.za
}

Received 8 August 2013; Revised 6 November 2013; Accepted 6 November 2013; Published 7 April 2014

Academic Editor: Theocharis C. Stamatatos

Copyright (C) 2014 A. O. Adeloye and P. A. Ajibade. This is an open access article distributed under the Creative Commons Attribution License, which permits unrestricted use, distribution, and reproduction in any medium, provided the original work is properly cited.

\begin{abstract}
The synthesis of single- and double-decked anthracenyl functionalized ruthenium(II) phthalocyanine complexes has been achieved through a controlled electrophilic aromatic substitution reaction of the free unsubstituted ruthenium(II) phthalocyanine with preformed 9-bromo-10-(2,3-dimethylacrylic acid)-anthracene and/or 9-bromo-10-(2,3-dimethylacrylic acid)-dianthracene using 1,8-diazabicyclo[5.4.0] undec-7-ene (DBU) as catalyst. The complexes were characterized by IR, UV-Vis, fluorescence, ${ }^{1} \mathrm{H},{ }^{13} \mathrm{C} \mathrm{NMR}$, and elemental analyses. A dimeric complex $\left(\mathbf{C}_{3} \mathbf{R}^{\prime \prime} \mathbf{R u P c}\right.$, where $\mathbf{R}^{\prime \prime}$ is 9-dianthracenyl-10-(2,3-dimethylacrylic acid), obtained as the major product of the dianthracenyl-substituted ruthenium phthalocyanine complex displays a strong near-infrared visible absorption band wavelength maxima at $1027 \mathrm{~nm}\left(\varepsilon=5.47 \times 10^{3} \mathrm{M}^{-1} \mathrm{~cm}^{-1}\right)$, with an interesting photoluminescent and electroredox active properties.
\end{abstract}

\section{Introduction}

Phthalocyanines (Pcs) are a widely studied class of organic chromophores [1]. They have proved useful for a variety of applications ranging from molecular electronic to medicine [2]. Their utility derives, in part, from the ease with which their properties can be modified through synthetic manipulation. Syntheses of new Pcs typically concentrate on a combination of modifications of the benzenoid substituents and variation of the central metal ion. With regard to metal ion insertion, attention has focused most extensively on metal(II) and metal(III) derivatives, the latter providing a further site for incorporation of a substituent as an axial ligand [1].

In general, metallated phthalocyanines are prepared by two methods: (i) cyclotetramerisation of a phthalic acid derivative (such as a phthalonitrile or diiminoisoindoline) in the presence of a metal salt and (ii) insertion of the desired metal ion into the preformed phthalocyanine ring either as its metal-free or dilithiated derivative [3-6]. The more commonly used method for the preparation of ruthenium phthalocyanine derivatives has tended to be the former and the two ruthenium reagents frequently used for the synthesis of ruthenium phthalocyanines are $\mathrm{RuCl}_{3}$ and $\left[\mathrm{Ru}_{3}(\mathrm{CO})_{12}\right]$ $[7,8]$. Introduction of substituents into the precursors such as phthalonitriles and final condensation to Pcs are common synthetic routes of which MPc with interesting photochemical and photophysical characteristics being made. Despite this, a precursor with specified substituents is not always readily available or, in other instances, hard to condense to Pc $[9,10]$. In this situation, introducing substituents to Pc directly instead of introducing them to the precursor is needed. However, direct substitution of the Pc ring often results in mixtures [11]. One method to reduce position indeterminacy is displacement of a group readily introduced to a precursor which is easy to condense to Pc.

In the present work, however, we focused our attention on the incorporation of ruthenium as the metal center into the cavity of nonperipheral substituted phthalocyanines using $\mathrm{RuCl}_{2}(\mathrm{DMSO})_{4}$ as metal precursor [12] and functionalized anthracene [13-15] derivatives as substituents and, most importantly, on developing an efficient, direct synthesis 
for these compounds. A direct substitution method may be useful in the syntheses of Pc most importantly where substituents are not stable in the condensation of precursor or the condensation is not qualitative [16]. When doing so, we have identified convenient methods for preparing doubly ligated derivatives bearing either two identical or nonidentical ligands. These findings have been exploited to synthesize tetrakis-(9-anthracenyl-10-(2,3-dimethylacrylic acid)-dicarbonyl ruthenium phthalocyanine) $\left(\mathbf{C}_{\mathbf{1}} \mathbf{R}^{\prime} \mathbf{R u P c}\right)$, (9-dianthracenyl-10-(2,3-dimethylacrylic acid)-dicarbonyl ruthenium phthalocyanine) $\left(\mathbf{C}_{\mathbf{2}} \mathbf{R}^{\prime \prime} \mathbf{R u P c}\right)$, and bis(9-dianthracenyl-10-(2,3-dimethylacrylic acid)-dicarbonyl diruthenium phthalocyanine) $\left(\mathbf{C}_{3} \mathbf{R}^{\prime \prime} \mathbf{R u P c}\right)$ complexes by direct electrophilic aromatic substitution of the protons on the Pc ring.

\section{Experimental}

2.1. Material. All chemical and reagents were analytically pure and used without further purification. 9-Anthracenyl10-(2,3-dimethylacrylic acid) and 9-dianthracenyl-10-(2,3dimethylacrylic acid) were synthesized as described in the literature [14]. The ruthenium(II) phthalocyanine complexes were synthesized as reported in the literature with slight modifications [16]. All thin layer chromatography (tlc) analyses were done with aluminum sheet precoated with normal phase silica gel $60 \mathrm{~F}_{254}$ (Merck, $0.20 \mathrm{~mm}$ thickness), except otherwise stated. The tlc plates were developed using any of the following solvent systems.

Solvent system A consists of dichloromethane-methanol $(9: 1)$, solvent system B consists of dichloromethane-methanol $(1: 1)$, solvent system $C$ consists of methanol-toluene (1:1), and solvent system D consists of diethylether-methanol $(1: 1)$. Column chromatography was performed using aluminum oxide 90 (Merck), previously soaked in methanolether $(50 \%, v / v)$.

2.2. Equipment. Melting points were determined using Gallenkamp electrothermal melting point apparatus. Microanalyses $(\mathrm{C}, \mathrm{H}, \mathrm{N})$ were carried out with a Fisons elemental analyser and infrared spectra were obtained with $\mathrm{KBr}$ discs or nujol on a Perkin Elmer System 2000 FT-IR spectrophotometer. UV-Vis and fluorescence spectra were recorded in $1 \mathrm{~cm}$ path length quartz cell on a Perkin Elmer Lambda 35 spectrophotometer and Perkin Elmer Lambda 45 spectrofluorometer, respectively. ${ }^{1} \mathrm{H}$ and ${ }^{13} \mathrm{C}$ Nuclear Magnetic Resonance spectra were run on a Bruker EMX $400 \mathrm{MHz}$ spectrometer for ${ }^{1} \mathrm{H}$ and $100 \mathrm{MHz}$ for ${ }^{13} \mathrm{C}$. The chemical shift values were reported in parts per million ( $\mathrm{ppm}$ ) relative to TMS as internal standard. Chemical shifts were also reported with respect to $\mathrm{CDCl}_{3}$ at $\delta_{\mathrm{c}} 77.00$ and $\delta_{\mathrm{H}} \mathrm{CDCl}_{3}$ at 7.25 and DMSO d $_{6}$ at $\delta_{c} 40.98$ and DMSO d ${ }_{6}$ at $\delta_{\mathrm{H}} 2.50$ for synthesized ligands and complexes. All electrochemical experiments were performed using Autolab potentiostat PGSTAT 302 (EcoChemie, Utrecht, The Netherlands) driven by the general purpose Electrochemical System data processing software (GPES, software version 4.9). A conventional three-electrode system was used. The working electrode was a bare glassy carbon electrode (GCE), and $\mathrm{Ag} \mid \mathrm{AgCl}$ wire and platinum wire were used as the pseudoreference and auxiliary electrodes, respectively. The potential response of the $\mathrm{Ag} \mid \mathrm{AgCl}$ pseudoreference electrode was less than the $\mathrm{Ag} \mid \mathrm{AgCl}(3 \mathrm{M}$ $\mathrm{KCl}$ ) by $0.015 \pm 0.003 \mathrm{~V}$. Prior to use, the electrode surface was polished with alumina on a Buehler felt pad and rinsed with excess millipore water. All electrochemical experiments were performed in freshly distilled dry DMF containing $\mathrm{TBABF}_{4}$ as supporting electrolyte.

\subsection{Synthesis}

2.3.1. Synthesis of 9-Bromo-10-(2,3-dimethylacrylic acid)anthracene (1). One gram of 9,10-dibromoanthracene $(2.90 \mathrm{mmol})$ was dissolved in $160 \mathrm{~mL}$ volume benzenedichloromethane mixture $(7: 3, \mathrm{v} / \mathrm{v})$, followed by addition of 2,3-dimethylacrylic acid $(0.30 \mathrm{~g}, 2.90 \mathrm{mmol})$. The mixture was stirred continuously for 10 minutes and triethylamine $(2.0 \mathrm{~mL})$, potassium hydroxide $(0.16 \mathrm{~g}, 2.90 \mathrm{mmol})$, and palladium-carbide $(35 \mathrm{mg})$ were added. The mixture was refluxed for $8 \mathrm{~h}$, while reaction progress was monitored by thin layer chromatography using any of the listed solvent systems A, B, or C. The crude product was filtered and concentrated in vacuo to afford a yellow solid. Degassed water was added to the solid to wash off the triethylamine and other unwanted side products. The yellow solution was extracted with chloroform, concentrated in vacuo, and further recrystallized in $50 \%$ ethanol-ether mixture to afford 9-bromo-10-(2,3-dimethylacrylic acid) (1) (Yield $=0.74 \mathrm{~g}$, $56.9 \%$, Mp. $\left.198-210^{\circ} \mathrm{C}\right)$. IR (KBr) $\nu_{\max } / \mathrm{cm}^{-1}: 3413(\mathrm{OH})$, 3076, 3027 (OH, $\alpha, \beta$-unsaturated acid), 2971, $2866(\mathrm{C}-\mathrm{H})$, $1929,1737,(\mathrm{C}=\mathrm{O}), 1632,1621,1522,1437,1365,1304,1256,1227$, $1162,1149,1028,960,926,844,746,675,604,578,528$.

2.3.2. Synthesis of 9-Bromo-10-(2,3-dimethylacrylic acid)dianthracene (2). Treatment of (1) $(0.50 \mathrm{~g}, 1.40 \mathrm{mmol})$ with 9,10-dibromoanthracene $(0.47 \mathrm{~g}, 1.40 \mathrm{mmol})$ using the same solvent mixture, reaction conditions, and purification steps (Section 2.3.1) afforded (2) (green solid; yield $=0.46 \mathrm{~g}, 47.4 \%$; $\left.\mathrm{M} . \mathrm{pt}=210-211^{\circ} \mathrm{C}\right) \cdot \mathrm{IR}(\mathrm{KBr}) v_{\max } / \mathrm{cm}^{-1}: 3413(\mathrm{OH}), 3076,3027$ (OH, $\alpha, \beta$-unsaturated acid), 2928, $2865(\mathrm{C}-\mathrm{H}), 1947,1927$, $(\mathrm{C}=\mathrm{O}), 1621,1522,1437,1385,1349,1304,1256,1162,1148,1027$, $960,926,838,746,675,604,578$.

2.3.3. Synthesis of Tetrakis-(9-anthracenyl-10-(2,3-dimethylacrylic acid)-dicarboxyl Ruthenium(II) Phthalocyanine $\left(C_{\mathbf{1}} \boldsymbol{R}^{\prime} \boldsymbol{R} \boldsymbol{u} \boldsymbol{P c}\right)$. [ $\left.\mathrm{RuCl}_{2}(\mathrm{DMSO})_{4}\right]$, used as metal precursor, was synthesized as reported [12]. The [RuPc] complexes were synthesized following literature procedure [16] with slight modifications as follows. In a $250 \mathrm{~mL}$ flask, $\left[\mathrm{RuCl}_{2}(\mathrm{DMSO})_{4}\right](0.500 \mathrm{~g}, 1.032 \mathrm{mmol})$ and phthalonitrile $(0.529 \mathrm{~g}, 4.128 \mathrm{mmol})$ were dissolved in $40 \mathrm{~mL}$ DMF and DBU $1.0 \mathrm{~mL}$ was added. The mixture was heated to reflux for $5 \mathrm{~h}$. To the purple solution, 9-bromo-10-(2,3-dimethylacrylic acid)-anthracene (1) $(1.462 \mathrm{~g}, 4.12 \mathrm{mmol}), \mathrm{KOH}(0.231 \mathrm{~g}$, $4.12 \mathrm{mmol})$, and triethylamine $(1.0 \mathrm{~mL})$ were added and the mixture was further refluxed for $2 \mathrm{~h}$. The dark blue-green solution was concentrated in vacuo to remove DMF. The 
crude product was redissolved in ether-methanol solution and chromatographed on alumina using the same solvent system for elution $\left(50 \%, 500 \mathrm{~mL}, \mathrm{v} / \mathrm{v}\right.$, isocratic elution, $\mathrm{R}_{\mathrm{f}}=$ $0.76)$ to afford a dark-green viscous liquid. Ethanol $(50 \mathrm{~mL})$ was added to the dark-green viscous liquid and heated to boiling, filtered hot, and concentrated in vacuo to afford a green liquid which was precipitated with diethyl-ether to afford the desired complex $\left(\mathbf{C}_{\mathbf{1}} \mathbf{R}^{\prime} \mathbf{R u P c}\right)$ (green solid, yield = $0.322 \mathrm{~g}, 16.4 \%)$.

IR $(\mathrm{KBr}) v_{\max } / \mathrm{cm}^{-1}: 3218(\mathrm{OH}), 3035(\mathrm{OH}, \alpha, \beta-$ unsaturated acid), 2910, 2846, $1938(\mathrm{C}=\mathrm{O}), 1688,1605(\mathrm{C}=\mathrm{C})$, $1472(\mathrm{C}=\mathrm{N}), 1461,1432,1311,1281,1165,1117,1059,774,741,732$. UV-Vis (dimethylformamide) $\lambda_{\max } / \mathrm{nm}\left(\varepsilon=\mathrm{M}^{-1} \mathrm{~cm}^{-1}\right): 331$ (15520), 350 (18145), 369 (215 77), 388 (18000), 573 (3147), 633 (7206), 902 (16800). Emission wavelength: $\left(\lambda_{\text {exc. }}=640 \mathrm{~nm}\right.$, $\left.\lambda_{\mathrm{em}}=672 \mathrm{~nm}\right) .{ }^{1} \mathrm{H}$ NMR $\left(\mathrm{CDCl}_{3}\right): \delta 8.43(\mathrm{~s}), 8.01(\mathrm{~m}), 7.47$ $(\mathrm{dd}, J=3.2,6.4 \mathrm{~Hz}), 2.93(\mathrm{~s}), 2.88(\mathrm{~s}), 2.57(\mathrm{~s}), 2.17(\mathrm{~s}) .{ }^{13} \mathrm{C}$ $\operatorname{NMR}\left(\mathrm{CDCl}_{3}\right): \delta 166.04,162.93,162.74,132.08,129.72,129.01$, 128.54, 127.11, 126.59, 125.75, 125.56, 124.31, 39.37, 23.83, 19.56. Anal. Calcd. for $\mathrm{C}_{110} \mathrm{H}_{72} \mathrm{~N}_{8} \mathrm{RuO}_{10}$ (1766.90): C, 74.78; H, 4.11; N, 6.34. Found: C, 75.12; H, 4.57; N, 6.91.

2.3.4. Synthesis of 9-Dianthracenyl-10-(2,3-dimethylacrylic acid)-dicarboxyl Ruthenium(II) Phthalocyanine Complexes: $\left(C_{2} R^{\prime \prime} R u P c\right)$ and $\left(C_{3} R^{\prime \prime} R u P c\right)$. The method employed for the synthesis was followed as reported in Section 2.3.3 above. A mixture of phthalonitrile $(0.53 \mathrm{~g}, 4.13 \mathrm{mmol})$, $\mathrm{RuCl}_{2}(\mathrm{DMSO})_{4}(0.50 \mathrm{~g}, 1.03 \mathrm{mmol})$, and $\mathrm{DBU}(1.0 \mathrm{~mL})$ was refluxed for $5 \mathrm{~h}$. This is followed by the addition of 9bromo-10-(2,3-dimethylacrylic acid)-dianthracene $(0.55 \mathrm{~g}$, $1.03 \mathrm{mmol}), \mathrm{KOH}(0.058 \mathrm{~g}, 1.03 \mathrm{mmol})$, and triethylamine $(1.0 \mathrm{~mL})$; the mixture was further refluxed for $2 \mathrm{~h}$. Two products were isolated from chromatographic column as $\left(\mathbf{C}_{2} \mathbf{R}^{\prime \prime} \mathbf{R u P c}\right.$ ) (blue-green solid, yield $=0.38 \mathrm{~g}, 24.1 \%, \mathrm{R}_{\mathrm{f}}=$ $0.65)$, and $\left(\mathbf{C}_{3} \mathbf{R}^{\prime \prime} \mathbf{R u P c}\right.$ ) (deep green solid, yield $=1.17 \mathrm{~g}$, $\left.73.9 \%, \mathrm{R}_{\mathrm{f}}=0.53\right)$.

$\left(\mathbf{C}_{2} \mathbf{R}^{\prime \prime} \mathbf{R u P c}\right):$ IR (KBr) $v_{\max } / \mathrm{cm}^{-1}: 3392,3194(\mathrm{OH})$, 3081, $3024(\mathrm{OH}, \alpha, \beta$-unsaturated acid), 2929, 2859, 2803 $(\mathrm{C}-\mathrm{H}), 1934,1642(\mathrm{C}=\mathrm{O}), 1586(\mathrm{C}=\mathrm{N}), 1468,1443,(\mathrm{C}=\mathrm{C})$, 1321, 1288, 1245, 1204, 1121, 1089, 984, 885, 754, 690, 607. UV-Vis (dimethylformamide) $\lambda_{\max } / \mathrm{nm}\left(\varepsilon=\mathrm{M}^{-1} \mathrm{~cm}^{-1}\right): 323$ (43190), 343 (36160), 368 (32720), 388 (28600), 566 (13300), 618 (19070). Emission wavelength: $\left(\lambda_{\text {exc. }}=640 \mathrm{~nm}, \lambda_{\text {em }}=\right.$ $682 \mathrm{~nm}$ ). Anal. Calcd. for $\mathrm{C}_{57} \mathrm{H}_{38} \mathrm{~N}_{8} \mathrm{RuO}_{4}$ (1000.05): C, 68.46; $\mathrm{H}, 3.83 ; \mathrm{N}, 11.20$. Found: $\mathrm{C}, 69.18 ; \mathrm{H}, 4.21 ; \mathrm{N}, 11.72 .\left({ }^{1} \mathrm{H}\right.$ and ${ }^{13} \mathrm{C}$ NMR spectra were not satisfactory).

$\left(\mathbf{C}_{3} \mathbf{R}^{\prime \prime} \mathbf{R u P c}\right)$ : IR (KBr) $v_{\max } / \mathrm{cm}^{-1}: 3307$ (br), 3038, 2911, 2835, 2507 (br), 1922, 1688, 1628, 1615, 1485, 1441, 1413, 1384, $1308,1284,1166,1116,1061,955,882,758,742,723,719$. UV-Vis (dimethylformamide) $\lambda_{\max } / \mathrm{nm}\left(\varepsilon=\mathrm{M}^{-1} \mathrm{~cm}^{-1}\right): 351$ (13104), 377 (11129), 561 (51320), 620 (96490), 631 (90350), 901 (19300), 1027 (54720). Emission wavelength: $\left(\lambda_{\text {exc. }}=640 \mathrm{~nm}, \lambda_{\mathrm{em}}\right.$ $=700 \mathrm{~nm}) .{ }^{1} \mathrm{H}$ NMR $\left(\right.$ DMSO- $\left.\mathrm{d}_{6}\right): \delta 1.51(\mathrm{~s}, 3 \mathrm{H}), 2.73-3.42$ $(\mathrm{m}, 11 \mathrm{H}), 7.50(\mathrm{dd}, J=2.4,6.8 \mathrm{~Hz}, 8 \mathrm{H}), 7.96(\mathrm{~s}), 8.09$ (dd, $J=3.2,6.4 \mathrm{~Hz}), 8.33(\mathrm{~s}, 1 \mathrm{H}), 8.55(\mathrm{~s}, 1 \mathrm{H}), 9.12(\mathrm{br}, 1 \mathrm{H})$. ${ }^{13}$ C NMR (DMSO- $\mathrm{d}_{6}$ ): $\delta 175.43,166.14,163.17,163.13,161.88$, 143.42, 141.12, 134.90, 134.84, 132.08, 128.88, 126.86, 126.40, 121.85, 80.11, 54.19, 26.75, 24.17, 23.93, 19.71. Anal. Calcd. for $\mathrm{C}_{132} \mathrm{H}_{76} \mathrm{~N}_{16} \mathrm{Ru}_{2} \mathrm{O}_{6}$ (2184.30): C, 72.58; H, 3.51; N, 10.26 . Found: C, 73.16; H, 4.19; N, 10.82 .

\section{Results and Discussion}

3.1. Synthesis. The preparation of phthalocyanines relies on the availability of the precursor phthalonitriles which undergo cyclotetramerization to form the macrocycles [17, 18]. It is to be noted that a direct palladium catalyzed cross-coupling reaction of functionalized bromoanthracenyl derivatives with bromophthalonitrile to form anthracenyl phthalonitrile prior to condensation to phthalocyanine was not successful. However, Lin Mei-jin and coworkers [16] reported a convenient synthesis of a substituted phthalocyanine compounds using bromosubstituted phthalonitrile as precursor followed by a nucleophilic substitution reaction of the bromogroup. A reverse synthetic procedure in which bromofunctionalized anthracene derivatives were reacted directly in an electrophilic aromatic substitution of the protons of the free ruthenium phthalocyanine afforded the desired products (Scheme 1). The reaction of ruthenium phthalocyanine $(\mathrm{RuPc})$ with either 9-bromo-10-(2,3dimethylacrylic acid)-anthracene and/or 9-bromo-10-(2,3dimethylacrylic acid)-dianthracene gave two products each after column chromatography. On the other hand, no Q-band absorption value was obtained for the product with singlelinked anthracenyl RuPc.

3.2. Infrared Spectra. The infrared spectra of the two functionalized anthracenyl ruthenium(II) phthalocyanines were carefully compared with the unsubstituted ruthenium(II) phthalocyanine precursor and bands were assigned accordingly. A strong $\mathrm{OH}$ vibrational stretch characteristic of $\alpha, \beta$ unsaturated carboxylic acid was found as a broad band at $3413 \mathrm{~cm}^{-1}$ for both mono- and dianthracenyl derivatives. This band was shifted to lower frequency $\left(c a .195 \mathrm{~cm}^{-1}, 21 \mathrm{~cm}^{-1}\right.$, and $\left.96 \mathrm{~cm}^{-1}\right)$, respectively, for $\left(\mathbf{C}_{1} \mathbf{R}^{\prime} \mathbf{R u P c}, \mathbf{C}_{2} \mathbf{R}^{\prime \prime} \mathbf{R u P c}\right.$, and $\mathrm{C}_{3} \mathrm{R}^{\prime \prime} \mathbf{R u P c}$ ). Common to the anthracenyl ligands and the complexes were two stretching vibrational bands between 3081 and $2857 \mathrm{~cm}^{-1}$ that were assigned to the methyl groups in the molecules. The infrared spectra of complexes with axial carbonyl ligands have characteristic bands in the region $1922-1965 \mathrm{~cm}^{-1}$ assigned to $v(\mathrm{C}-\mathrm{O})$ [19-21]. Bands at 1688 , 1642 , and $1321 \mathrm{~cm}^{-1}$ were unambiguously assigned to the $\nu(\mathrm{C}=\mathrm{O})$ and $\nu(\mathrm{C}-\mathrm{O})$ stretching of carboxylic acid groups in the complexes. The bands in the regions 1642 and $1441 \mathrm{~cm}^{-1}$ contain contributions mostly from the atoms in the pc rings near to the metal; these peaks have been found to be sensitive to the central metal atom [22]. It is well known that different polymorphic organizations of phthalocyanines also show different IR absorbance patterns which can be useful in identifying and characterizing a particular form or dimorphic transition. In particular, in the range between 800 and $700 \mathrm{~cm}^{-1}$, the out-of-plane $\mathrm{C}-\mathrm{H}$ bending vibrations are expected. In fact, due to the sensitivity of these vibrations to the molecular packing, the major differences reported so far for both metallated phthalocyanines and the free ligand of different polymorphic structures were discovered 


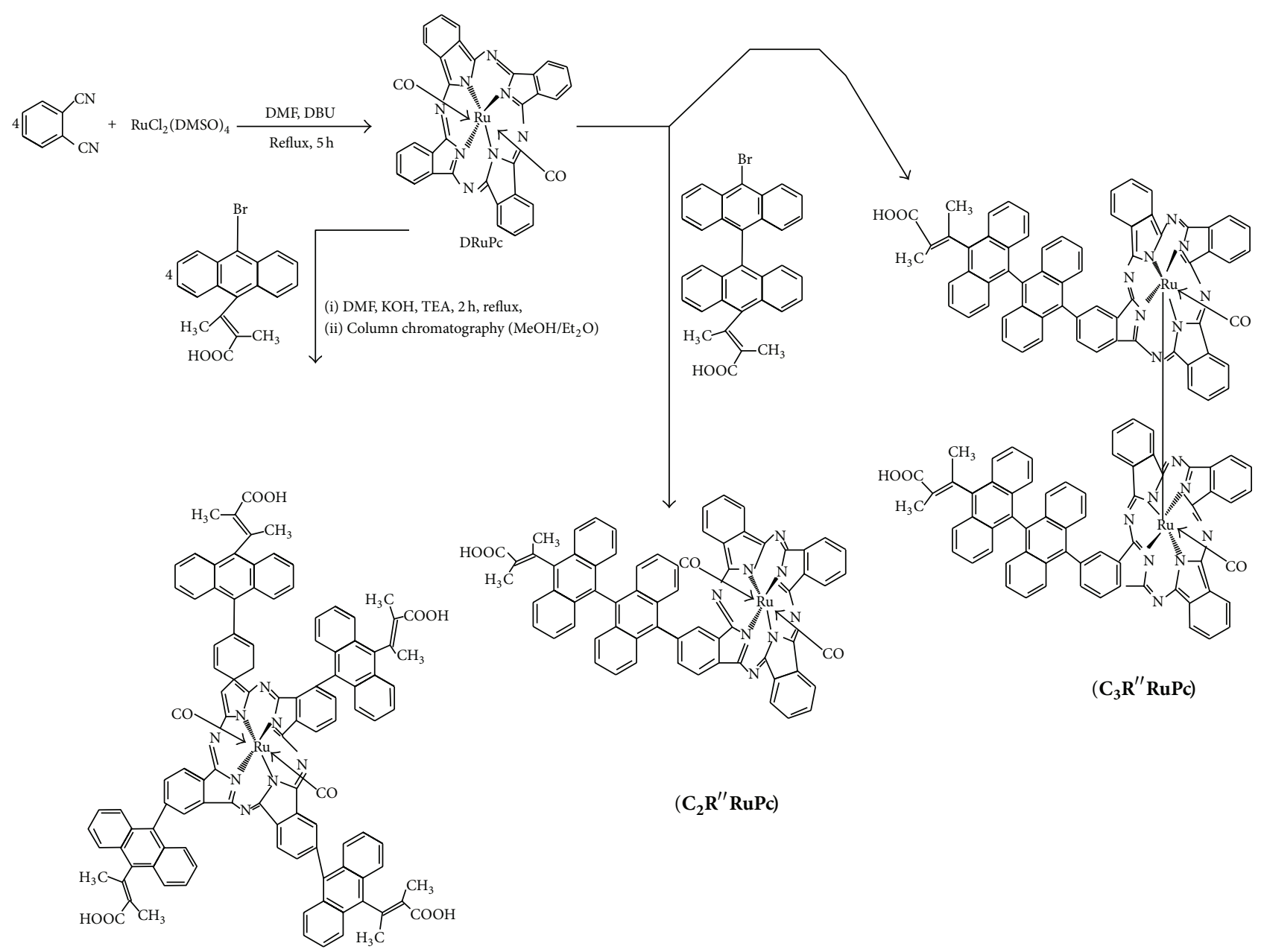

$\left(\mathbf{C}_{1} \mathbf{R}^{\prime} \mathbf{R u P c}\right)$

Scheme 1: Reaction scheme showing electrophilic substitution on RuPc.

in this range [23]. As can be seen, the spectra are very similar in the shown range, but, in the above-mentioned region, some differences can be noticed: the three-band system is constituted in $\left(\mathbf{C}_{\mathbf{1}} \mathbf{R}^{\prime} \mathbf{R u P c}\right)$ by well-defined bands at 732,741 , and $744 \mathrm{~cm}^{-1}$, while, in $\left(\mathbf{C}_{2} \mathbf{R}^{\prime \prime} \mathbf{R u P c}\right)$, the first one is centered at $728 \mathrm{~cm}^{-1}$ with a pronounced shoulder at $754 \mathrm{~cm}^{-1}$ and, in the third, $\left(\mathbf{C}_{3} \mathbf{R}^{\prime \prime} \mathbf{R u P c}\right)$ is found at 742,723 , and $758 \mathrm{~cm}^{-1}$ with a shoulder at $719 \mathrm{~cm}^{-1}$. In the neighborhood of $900-960 \mathrm{~cm}^{-1}$, a strong sharp peak was observed in $\left(\mathbf{C}_{3} \mathbf{R}^{\prime \prime} \mathbf{R u P c}\right)$ which was conspicuously absent in $\left(\mathbf{C}_{1} \mathbf{R}^{\prime} \mathbf{R u P c}\right)$ and $\left(\mathbf{C}_{2} \mathbf{R}^{\prime \prime} \mathbf{R u P c}\right)$. At this region, one can notice the disappearance and/or a low absorbance in the latter complexes, which can be attributed to different molecular packing in the molecules. These small differences in the IR spectra could well support the differences attributed to the complexes in the optical spectra reported below.

3.3. UV-Vis Absorption and Emission Spectra. The electronic spectra of ruthenium phthalocyanines $\left(\mathbf{C}_{1} \mathbf{R}^{\prime} \mathbf{R u P c}\right)$, $\left(\mathbf{C}_{2} \mathbf{R}^{\prime \prime} \mathbf{R u P c}\right)$, and $\left(\mathbf{C}_{3} \mathbf{R}^{\prime \prime} \mathbf{R u P c}\right)$ show the $\mathrm{Q}$ bands of a typical macrocycle substituted Pc [24-26]. The energy level location corresponding to this band is illustrated in (Figure 1). In the UV-region, anthracene displays strong absorptions between 300 and $400 \mathrm{~nm}$ in the solution, with pronounced vibronic peaks at $331,350,369$, and $388 \mathrm{~nm}$ characteristic of anthracene derivatives and with highest molar absorptivity coefficient recorded for $\mathbf{C}_{1} \mathbf{R}^{\prime} \mathbf{R u P c}$ [27]. The presence of these bands is thought to have overlapped the weak Soret band which normally appears in the region $340-385 \mathrm{~nm}$ and attributed to a charge transfer (CT) transition $[4,25,26]$.

In the visible region, $\left(\mathbf{C}_{1} \mathbf{R}^{\prime} \mathbf{R u P c}\right)$ and $\left(\mathbf{C}_{2} \mathbf{R}^{\prime \prime} \mathbf{R u P c}\right)$ showed single-broad Q-bands $(633,618 \mathrm{~nm})$ with accompanied weak shoulder bands at 573 and $566 \mathrm{~nm}$, respectively. The Q-band splitted into two $(620$ and $631 \mathrm{~nm})$ in $\left(\mathbf{C}_{3} \mathbf{R}^{\prime \prime} \mathbf{R u P c}\right)$ with corresponding weak shoulder band at $561 \mathrm{~nm}$. These absorptions were assigned to $\pi \rightarrow \pi^{*}$ transition within the macrocycle [7].

Coordination of a carbonyl ligand induces a bathochromic shift of $300-500 \mathrm{~cm}^{-1}$ and a significant increase in 


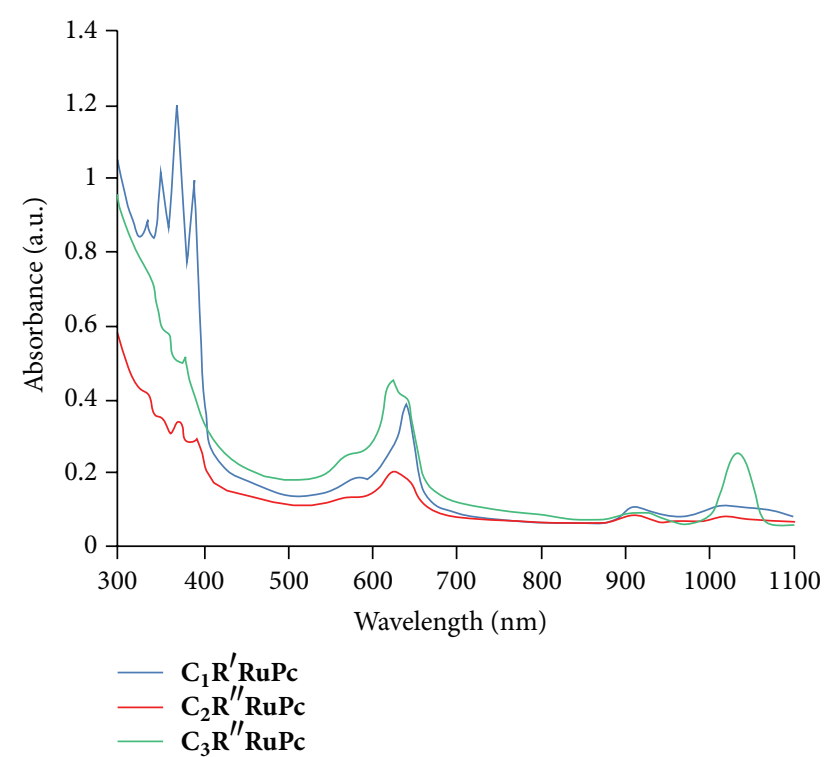

Figure 1: UV-Vis absorption spectra of $\left(\mathbf{C}_{\mathbf{1}} \mathbf{R}^{\prime} \mathbf{R u P c}\right),\left(\mathbf{C}_{\mathbf{2}} \mathbf{R}^{\prime \prime} \mathbf{R u P c}\right)$, and $\left(\mathbf{C}_{3} \mathbf{R}^{\prime \prime} \mathbf{R u P c}\right)$ in DMF solution.

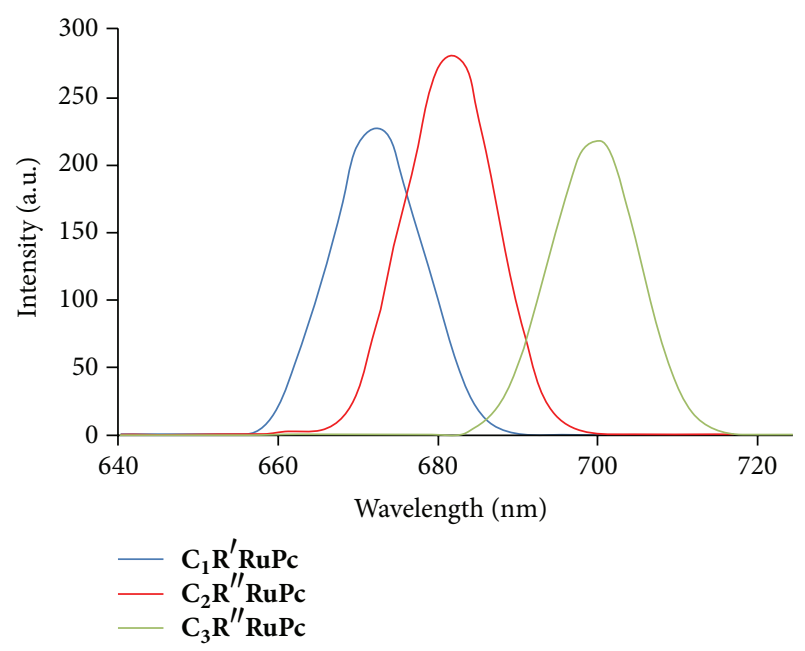

Figure 2: Emission spectra of $\left(\mathbf{C}_{1} \mathbf{R}^{\prime} \mathbf{R u P c}\right),\left(\mathbf{C}_{2} \mathbf{R}^{\prime \prime} \mathbf{R u P c}\right)$, and $\left(\mathbf{C}_{3} \mathbf{R}^{\prime \prime} \mathbf{R u P c}\right)$ in DMF solution.

the molar absorptivity [20]. The splitting of Q-band as found in $\left(\mathbf{C}_{3} \mathbf{R}^{\prime \prime} \mathbf{R u P c}\right)$ may be adduced to the new steric and symmetrical properties imposed on the complex by solvation of the phthalocyanine and axial ligands and the polar electronic influence of the solvents on the ligands. Peripheral substitution of the macrocycle has only a weak influence on the position of the Q-band. Hanack group reported that peripheral substitution with an electron-donating group causes a weak bathochromic shift of the Q-band [28]. The near-infrared absorption band in $\left(\mathbf{C}_{3} \mathbf{R}^{\prime \prime} \mathbf{R u P c}\right)$ was attributed to a better $\pi$-bond conjugation indicative of the synergy effect of the $\mathrm{Ru}-\mathrm{Ru}$ metal bond linkage of the dimeric complex.

The $\left(\mathbf{C}_{1} \mathbf{R}^{\prime} \mathbf{R u P c}\right), \quad\left(\mathbf{C}_{2} \mathbf{R}^{\prime \prime} \mathbf{R u P c}\right)$, and $\left(\mathbf{C}_{3} \mathbf{R}^{\prime \prime} \mathbf{R u P c}\right)$ complexes exhibit intense and long-lived orange-red lumine-

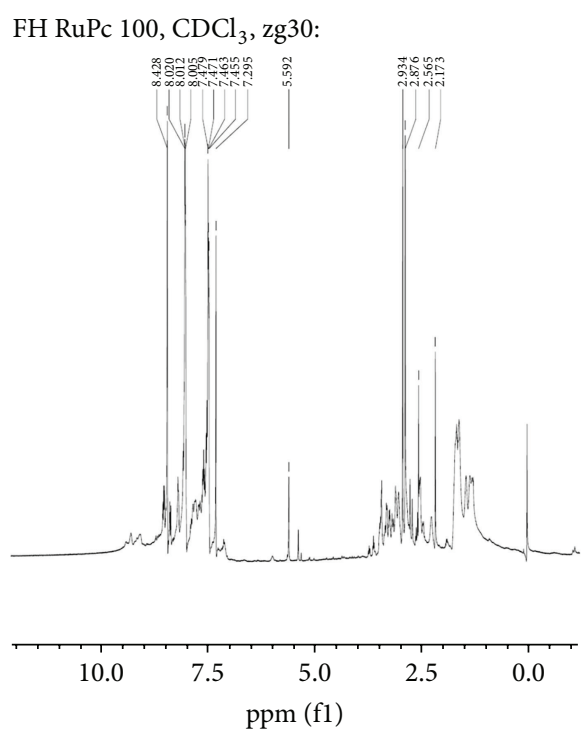

Figure 3: ${ }^{1} \mathrm{H}$ NMR spectrum of $\mathbf{C}_{1} \mathbf{R}^{\prime} \mathbf{R u P c}$.

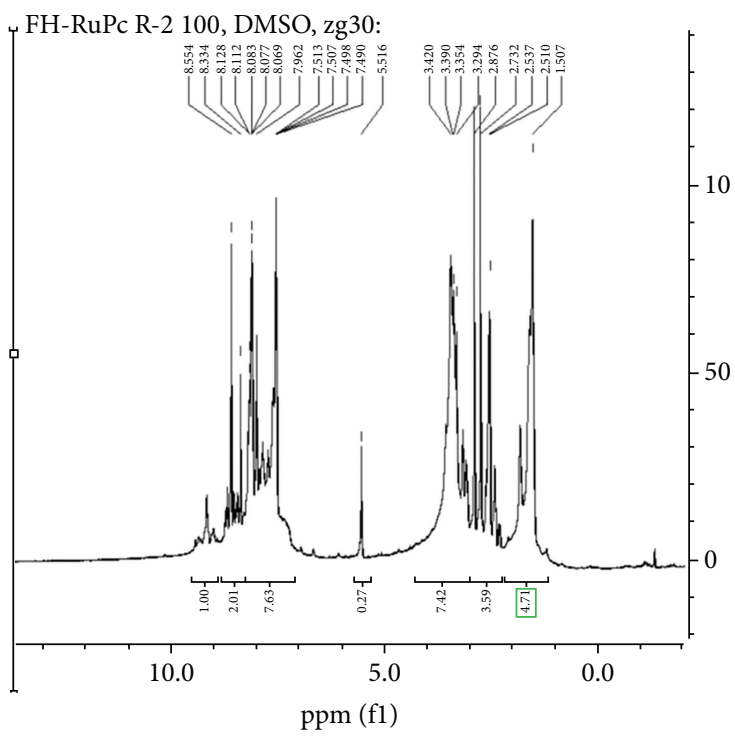

Figure $4:{ }^{1} \mathrm{H}$ NMR spectrum of $\mathbf{C}_{3} \mathbf{R}^{\prime \prime} \mathbf{R u P c}$.

scence upon irradiation in fluid solutions at $298 \mathrm{~K}$ ( $\lambda_{\text {exc }}$ $=640 \mathrm{~nm}$ ). The emission spectra are shown in Figure 2 . The emission maxima of the complexes $\left(\mathbf{C}_{1} \mathbf{R}^{\prime} \mathbf{R u P c}\right)$, $\left(\mathbf{C}_{2} \mathbf{R}^{\prime \prime} \mathbf{R u P c}\right)$, and $\left(\mathbf{C}_{3} \mathbf{R}^{\prime \prime} \mathbf{R u P c}\right)$ occur at 672,682 , and $700 \mathrm{~nm}$, respectively. The emission is likely to originate from an excited state of ${ }^{3}$ MLCT $\left(\mathrm{d} \pi(\mathrm{Ru}) \rightarrow \pi^{*}\right)$ macrocycle and anthracene characters. An extended $\pi$ system in the complexes has allowed a greater delocalization of the excited electron, which reduces the adjustments in local bond displacements and modulates the vibrational overlap between states $[14,29,30]$.

3.4. NMR Spectra. The ${ }^{1} \mathrm{H}$ NMR spectra for $\left(\mathbf{C}_{\mathbf{1}} \mathbf{R}^{\prime} \mathbf{R u P c}\right)$ and $\left(\mathbf{C}_{3} \mathbf{R}^{\prime \prime} \mathbf{R u P c}\right)$ (Figures 3 and 4$)$ show the expected aggregation and broadening of the signals. The $\mathrm{AA}^{\prime} \mathrm{BB}^{\prime}$ signals of the 


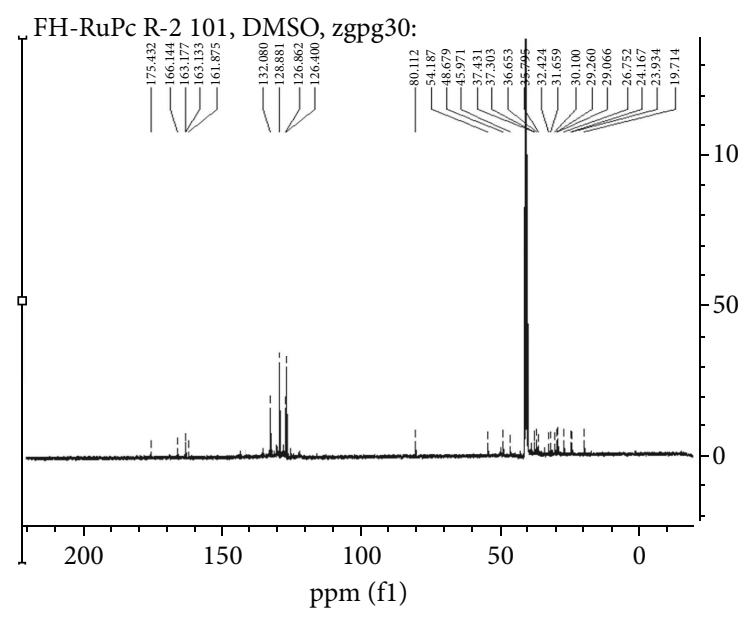

(a)

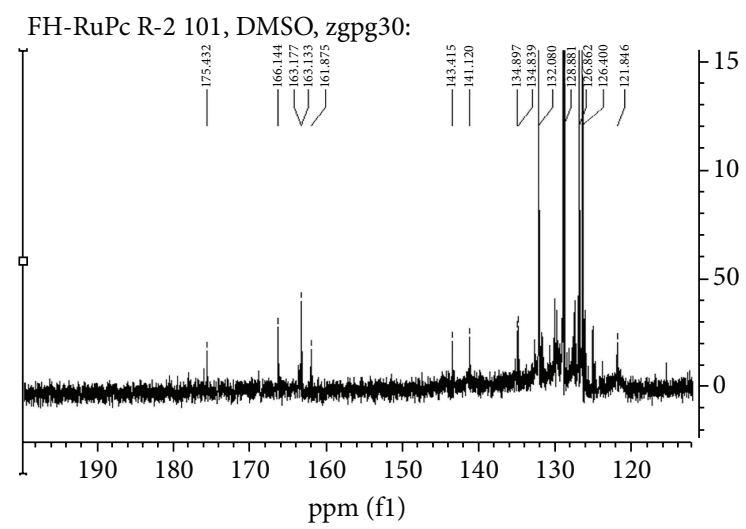

(b)

Figure 5: (a) ${ }^{13} \mathrm{C}$ NMR spectrum of $\mathbf{C}_{3} \mathbf{R}^{\prime \prime} \mathbf{R u P c}$. (b) Aromatic region of ${ }^{13} \mathrm{C}$ NMR spectrum of $\mathbf{C}_{3} \mathbf{R}^{\prime \prime} \mathbf{R u P c}$.

anthracene units in the aromatic region are well resolved and appear as doublet of doublet peaks at chemical shift values at $\delta 7.47,7.50$, and $8.09 \mathrm{ppm}$, respectively. In addition, the macrocyclic Pc ring protons were found as doublet at $\delta$ $8.01 \mathrm{ppm}$ and a singlet at $\delta 8.43 \mathrm{ppm}$ for $\left(\mathbf{C}_{\mathbf{1}} \mathbf{R}^{\prime} \mathbf{R u P c}\right)$ typical of AAAA-type coupling pattern, while an ABBB-type in $\left(\mathrm{C}_{3} \mathbf{R}^{\prime \prime} \mathbf{R u P c}\right)$ could be ascribed to the proton singlet peaks at $9.12,8.55,8.33$, and $7.96 \mathrm{ppm}$ [31]. The aliphatic region of the complexes $\left(\mathbf{C}_{\mathbf{1}} \mathbf{R}^{\prime} \mathbf{R u P c}\right)$ and $\left(\mathbf{C}_{3} \mathbf{R}^{\prime \prime} \mathbf{R u P c}\right)$ rather presents unstructured signals between 2.93 and $2.17 \mathrm{ppm}$. However, the methyl groups of the 2,3-dimethylacrylic acid moiety are strong and well resolved. The methyl groups increase the solubility and stability properties of the complexes.

In the ${ }^{13} \mathrm{C}$-NMR spectra of $\left(\mathbf{C}_{\mathbf{1}} \mathbf{R}^{\prime} \mathbf{R u P c}\right)$ and $\left(\mathbf{C}_{3} \mathbf{R}^{\prime \prime} \mathbf{R u P c}\right)$ (Figures 5 and 6 ), there are characteristic signals for the axial coordinated carbonyl groups which appear at $166.04 \mathrm{ppm}$ for $\left(\mathbf{C}_{1} \mathbf{R}^{\prime} \mathbf{R u P c}\right)$ and $175.43 \mathrm{ppm}$ for $\left(\mathbf{C}_{3} \mathbf{R}^{\prime \prime} \mathbf{R u P c}\right)$. The downfield shift may be ascribed to the steric hindrance in the dimer molecule. The extension of the $\pi$-conjugated bond as a result of the doubly linked anthracene and the dimeric nature of $\left(\mathbf{C}_{3} \mathbf{R}^{\prime \prime} \mathbf{R u P c}\right)$ complex appeared to have synergistic effects when compared to a monomeric anthracenyl substitution in

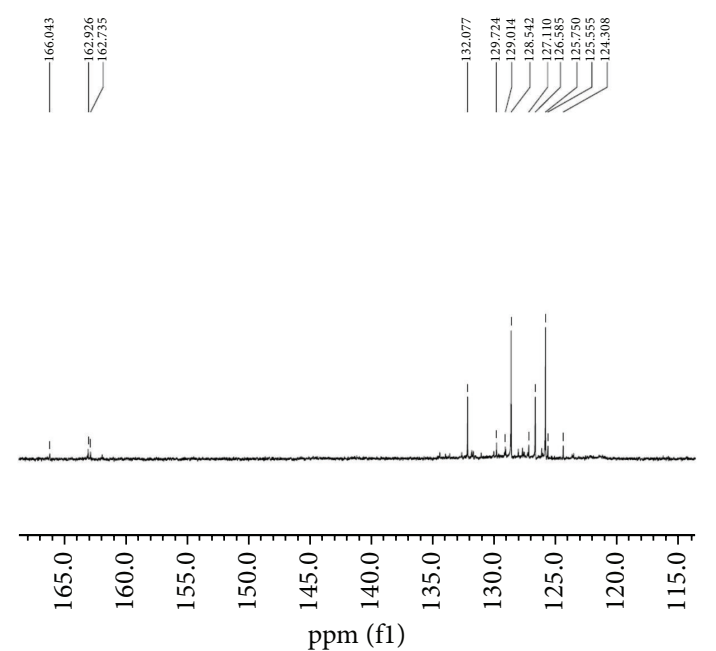

Figure 6: Aromatic region of ${ }^{13} \mathrm{C}$ NMR spectrum of $\mathbf{C}_{\mathbf{1}} \mathbf{R}^{\prime} \mathbf{R u P c}$.

$\left(\mathbf{C}_{\mathbf{1}} \mathbf{R}^{\prime} \mathbf{R u P c}\right)$. The carboxylic acid $(\mathrm{C}=\mathrm{O})$ functionalities are found as signals between $\delta 166.16$ and $161.88 \mathrm{ppm}$ for the two complexes. Also present in the spectra are two different peaks with high intensity at $\delta 128.88$ and $126.86 \mathrm{ppm}$ for $\left(\mathbf{C}_{\mathbf{1}} \mathbf{R}^{\prime} \mathbf{R u P c}\right)$ and $\delta 129.01$ and $125.75 \mathrm{ppm}$ for $\left(\mathbf{C}_{3} \mathbf{R}^{\prime \prime} \mathbf{R u P c}\right)$. These signals were unambiguously assigned to the anthracene molecular units in the complexes. The macrocyclic ring signals were found between $\delta 143.42$ and $132.84 \mathrm{ppm}$. The methyl groups were found as signals at $\delta 23.93$ and $19.56 \mathrm{ppm}$. A good ${ }^{1} \mathrm{H}$ and ${ }^{13} \mathrm{C}$ NMR resolution could not be obtained for $\left(\mathbf{C}_{2} \mathbf{R}^{\prime \prime} \mathbf{R u P c}\right)$.

3.5. Electrochemistry. Cyclic voltammograms were measured for the functionalized anthracenyl ruthenium(II) phthalocyanine complexes in $0.05 \mathrm{M}$ TBAH-DMF solution as shown in Figure 7. Similar electroredox properties were observed for $\left(\mathbf{C}_{1} \mathbf{R}^{\prime} \mathbf{R u P c}\right)$ and $\left(\mathbf{C}_{2} \mathbf{R}^{\prime \prime} \mathbf{R u P c}\right)$ (Plate 1). The two complexes show a reversible one-electron oxidation process at $+0.88 \mathrm{~V}$; this process involves the oxidation of the phthalocyanine macrocycle to give $\left[\mathrm{Pc}^{0} \mathrm{Ru}^{\mathrm{II}}(\mathrm{CO})_{2}\right]^{2+}$ species $[32,33]$. Oneelectron reduction process was observed in the two complexes at $-0.71 \mathrm{~V}$ and was assigned to reduction of the macrocycle and/or the anthracene unit [34]. The difference of $\sim 2 \mathrm{~V}$ between the first reduction and oxidation processes appears typical for this type of complex [20,34]. When compared to complexes of the type $\left[\mathrm{PC}^{0} \mathrm{Ru}^{\mathrm{II}} \mathrm{L}_{2}\right]^{2+}$ (where $\mathrm{L}$ is $\mathrm{N}$-donor ligands), the presence of $\mathrm{CO}$ always shows only one oxidation process at more positive potentials which may be expected due to greater $\pi$-back bonding of the ligated CO complexes [33]. The dimeric complex $\left(\mathbf{C}_{3} \mathbf{R}^{\prime \prime} \mathbf{R u P c}\right)$ (Plate 2) displays somewhat different redox behaviour to monomeric complexes $\left(\mathbf{C}_{\mathbf{1}} \mathbf{R}^{\prime} \mathbf{R u P c}\right)$ and $\left(\mathbf{C}_{2} \mathbf{R}^{\prime \prime} \mathbf{R u P c}\right)$. $\left(\mathbf{C}_{3} \mathbf{R}^{\prime \prime} \mathbf{R u P c}\right)$ undergoes centered oxidation, although the possibility of ringbased oxidation is also possible. The reduction process is attributed to either the addition of electrons into metal $\mathrm{d}\left(\pi^{*}\right)$ orbitals giving $\mathrm{Ru}^{1}-\mathrm{Ru}^{1}$ species or the electron reduction of the phthalocyanine macrocycle. The possibility of this to 


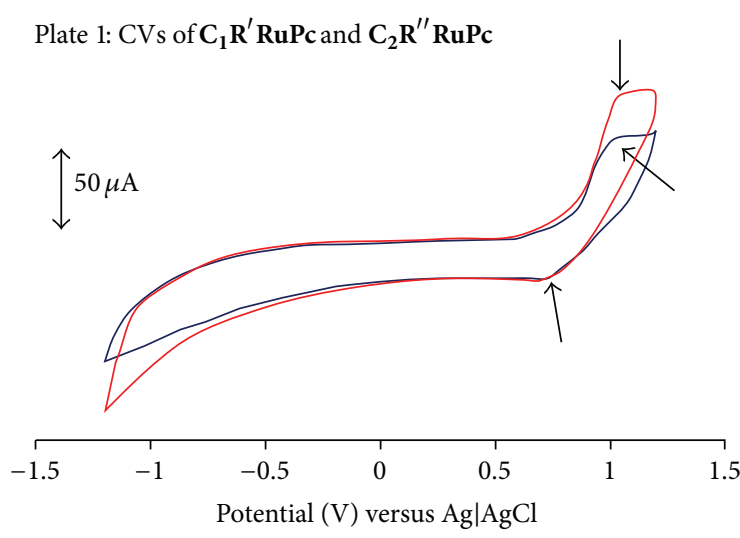

- (a) $\mathrm{C}_{1} \mathrm{R}^{\prime} \mathrm{RuPc}$

- (b) $\mathrm{C}_{2} \mathrm{R}^{\prime \prime} \mathrm{RuPc}$

Plate 2: $\mathrm{CV}$ of $\mathbf{C}_{3} \mathbf{R}^{\prime \prime} \mathbf{R u P c}$

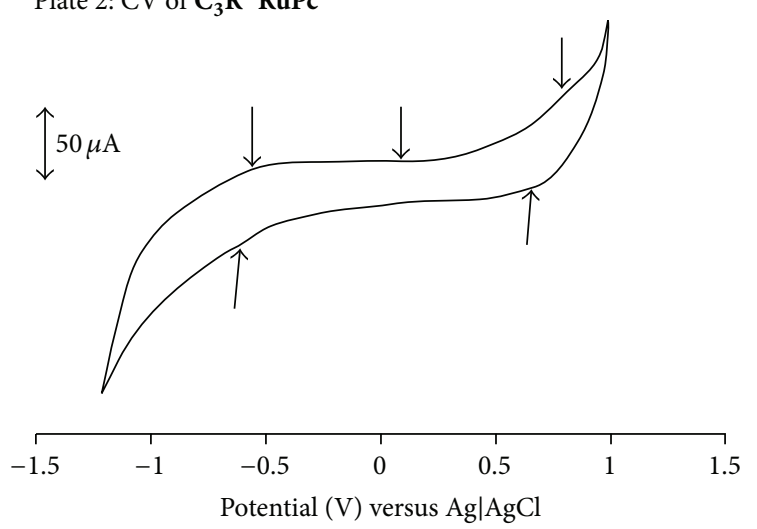

Figure 7: Cyclic voltammetry of $\left(\mathbf{C}_{1} \mathbf{R}^{\prime} \mathbf{R u P c}\right),\left(\mathbf{C}_{2} \mathbf{R}^{\prime \prime} \mathbf{R u P c}\right)$, and $\left(\mathrm{C}_{3} \mathrm{R}^{\prime \prime} \mathrm{RuPc}\right)$.

the electron-donor nature of the anthracene molecular unit is not excluded [34].

\section{Conclusion}

In summary, 9-bromo-10-(2,3-dimethylacrylic acid) anthracene and 9-bromo-10-(2,3-dimethylacrylic acid) dianthracene reacted conveniently with a nonsubstituted ruthenium phthalocyanine in an electrophilic aromatic substitution reaction. This route may be useful in some syntheses of substituted MPc, where the condensation reaction by the precursor bearing the target substitution group is difficult. The photophysical and electrochemical properties exhibited by ( $\left.\mathbf{C}_{\mathbf{1}} \mathbf{R}^{\prime} \mathbf{R u P c}\right),\left(\mathbf{C}_{2} \mathbf{R}^{\prime \prime} \mathbf{R u P c}\right)$, and $\left(\mathbf{C}_{3} \mathbf{R}^{\prime \prime} \mathbf{R u P c}\right)$ complexes make them suitable as potential materials for molecular electronic devices, most especially their use as sensitizers for dye-sensitized solar cells (DSSCs). The $\left(\mathbf{C}_{3} \mathbf{R}^{\prime \prime} \mathbf{R u P c}\right)$ complex due to its near-infrared absorption property could also serve as carrier generation material.

\section{Conflict of Interests}

The authors declare that there is no conflict of interests regarding the publication of this paper.

\section{Acknowledgments}

The financial support (Bursary) from the South African National Energy Research Institute (SANERI) and Govan Mbeki Research Centres, University of Fort Hare, Alice, South Africa, is appreciated. AOA acknowledges Obafemi Awolowo University, Nigeria, for study leave.

\section{References}

[1] N. B. Mckeown, Phthalocyanine Materials: Synthesis, Structure and Function, Cambridge University Press, Cambridge, UK, 1998.

[2] M. M. Nicolson, in Phthalocyanines, Propertiesand Applications, C. C. Leznoff and A. B. P. Lever, Eds., vol. 3, pp. 71-118, VCH, New York, NY, USA, 1993.

[3] B. D. Berezin and G. V. Sennikova, "New complex compounds of phthalocyanine with ruthenium and iridium," Doklady Akademii Nauk SSSR, vol. 159, no. 1, pp. 117-120, 1964.

[4] W. Kobel and M. Hanack, "Bisaxially coordinated (phthalocyaninato)ruthenium(II) compounds," Inorganic Chemistry, vol. 25, no. 1, pp. 103-107, 1986.

[5] G. Rossi, M. Gardini, G. Pennesi, C. Ercolani, and V. L. Goedken, "Notes. Ruthenium phthalocyanine chemistry: synthesis and properties of a mixed-valence nitrido-bridged ruthenium phthalocyanine dimer," Journal of the Chemical Society, Dalton Transactions, no. 1, pp. 193-195, 1989.

[6] A. Capobianchi, A. M. Paoletti, G. Pennesi, G. Rossi, R. Caminiti, and C. Ercolani, "Ruthenium phthalocyanine: structure, magnetism, electrical conductivity properties, and role in dioxygen activation and oxygen atom transfer to 1-octene," Inorganic Chemistry, vol. 33, no. 21, pp. 4635-4640, 1994.

[7] Y. G. Gorbunova, Y. Y. Enakieva, S. G. Sakharov, and A. Y. Tsivadze, "Synthesis and spectral properties of ruthenium(II) complexes with tetra-15-crown-5-phthalocyanine and N-donor ligands," Journal of Porphyrins and Phthalocyanines, vol. 7, no. 11-12, pp. 795-800, 2003.

[8] G. Berber, A. N. Cammidge, I. Chambrier, M. J. Cook, and P. W. Hough, "Controlled synthesis of ruthenium phthalocyanines and their use in the construction of supramolecular arrays," Tetrahedron Letters, vol. 44, no. 29, pp. 5527-5529, 2003.

[9] A. N. Cammidge, G. Berber, I. Chambrier, P. W. Hough, and M. J. Cook, "Octaalkylphthalocyaninato ruthenium(II) complexes with mixed axial ligands and supramolecular porphyrin:phthalocyanine structures derived from them," Tetrahedron, vol. 61, no. 16, pp. 4067-4074, 2005.

[10] J. Huang, N. Chen, J. Huang et al., "Metal phthalocyanine as photosensitizer for photodynamic therapy (PDT)-preparation, characterization and anticancer activities of an amphiphilic phthalocyanine ZnPcS2P2," Science in China B, vol. 44, no. 2, pp. 113-122, 2001.

[11] O. V. Shishkina, V. E. Maizlish, and G. P. Shaposhnikov, "Nucleophilic substitution in 4-bromo-5-nitrophthalodinitrile: IV. 5-nitro-4-(phenylthio)phthalodinitrile and octa-substituted metal phthalocyanines based thereon," Russian Journal of General Chemistry, vol. 71, no. 2, pp. 243-245, 2001.

[12] I. P. Evans, A. Spencer, and G. Wilkinson, "Dichlorotetrakis(dimethyl sulphoxide)ruthenium(II) and its use as a source material for some new ruthenium(II) complexes," Journal of the Chemical Society, Dalton Transactions, no. 2, pp. 204-209, 1973. 
[13] T. Yamamoto, K. Naoyuki, and F. Hiroki, "Method for producing a polymerized hydrocarbon," 2006, http://www.google .com/patents/US7138484.

[14] A. O. Adeloye and P. A. Ajibade, "Synthesis and characterization of a heteroleptic $\mathrm{Ru}$ (II) complex of phenanthroline containing Oligo-anthracenyl carboxylic acid moieties," International Journal of Molecular Sciences, vol. 11, no. 9, pp. 3158-3176, 2010.

[15] A. O. Adeloye and P. A. Ajibade, "Synthesis and characterization of a $\mathrm{Ru}$ (II) complex with functionalized phenanthroline ligands having single-double linked anthracenyl and 1-methoxy-1buten-3-yne moieties," Molecules, vol. 15, no. 11, pp. 7570-7581, 2010.

[16] M. J. Lin, J. D. Wang, N. S. Chen, and J. L. Huang, "A convenient synthesis of a substituted phthalocyanine compound," Journal of Coordination Chemistry, vol. 59, no. 6, pp. 607-611, 2006.

[17] D. Wöhrle, G. Schnurpfeil, and G. Knothe, "Efficient synthesis of phthalocyanines and related macrocyclic compounds in the presence of organic bases," Dyes and Pigments, vol. 18, no. 2, pp. 91-102, 1992.

[18] T. Fukuda, T. Ishiguro, and N. Kobayashi, "Non-planar phthalocyanines with Q-bands beyond $800 \mathrm{~nm}$," Tetrahedron Letters, vol. 46, no. 16, pp. 2907-2909, 2005.

[19] S. Omiya, M. Tsutsui, E. F. Meyer Jr., I. Bernal, and D. L. Cullen, "Synthesis and structure of a new class of metallophthalocyanines: carbonyl(phthalocyanato)(pyridine or tetrahydrofuran)ruthenium(II) and carbonyl(phthalocyanato)(pyridine or tetrahydrofuran)osmium(II)," Inorganic Chemistry, vol. 19, no. 1, pp. 134-142, 1980.

[20] D. Dolphin, B. R. James, J. Murray, and J. R. Thornback, "Synthetic and oxidation studies of ruthenium(II) phthalocyanine complexes," Canadian Journal of Chemistry, vol. 58, no. 11, pp. 1125-1132, 1980.

[21] T. Rawling and A. McDonagh, "Ruthenium phthalocyanine and naphthalocyanine complexes: synthesis, properties and applications," Coordination Chemistry Reviews, vol. 251, no. 910, pp. 1128-1157, 2007.

[22] I. M. Keen and B. W. Malerbi, “The preparation and infra-red spectra of phthalocyanine derivatives of the platinum-group metals," Journal of Inorganic and Nuclear Chemistry, vol. 27, no. 6, pp. 1311-1319, 1965.

[23] L. Alagna, A. Capobianchi, M. P. Casaletto et al., "Effect of molecular packing on the solid state spectra of ruthenium phthalocyanine: anomalous behaviour of a monodimensional stacked assembly," Journal of Materials Chemistry, vol. 11, no. 7, pp. 1928-1935, 2001.

[24] M. K. Nazeeruddin, R. Humphry-Baker, M. Grätzel, and B. A. Murrer, "Efficient near IR sensitization of nanocrystalline $\mathrm{TiO}_{2}$ films by ruthenium phthalocyanines," Chemical Communications, no. 6, pp. 719-720, 1998.

[25] M. Hanack and Y. G. Kang, "Synthesis and properties of (phthalocyaninato) ruthenium(II) with bisaxially coordinated azanaphthalences," Chemische Berichte, vol. 124, no. 7, pp. 16071612, 1991.

[26] W. Eberhardt and M. Hanack, "Synthesis of hexadecaalkylsubstituted metal phthalocyanines," Synthesis, no. 12, pp. 17601764, 1998.

[27] N. Godbert, M. R. Bryce, S. Dahaoui, A. S. Batsanov, J. A. K. Howard, and P. Hazendonk, "Hydroxymethyl-functionalised 9,10-bis(1,3-dithiol-2-ylidene)-9,10-dihydroanthracene $\pi$-electron donors as synthetic intermediates for supramolecular structures," European Journal of Organic Chemistry, no. 4, pp. 749-757, 2001.
[28] S. Knecht, R. Polley, and M. Hanack, "Synthesis of oligomeric axially bridged ruthenium phthalocyanines and 2,3-naphthalocyanines," Applied Organometallic Chemistry, vol. 10, no. 8, pp. 649-660, 1996.

[29] S. Leroy-Lhez, C. Belin, A. D’Aleo, R. M. Williams, L. De Cola, and F. Fages, "Extending excited-state lifetimes by interchromophoric triplet-state equilibration in a pyrene-Ru(II)diimine dyad system," Supramolecular Chemistry, vol. 15, no. 7-8, pp. 627-637, 2003.

[30] A. P. de Silva, D. B. Fox, T. S. Moody, and S. M. Weir, "Luminescent sensors and photonic switches," Pure and Applied Chemistry, vol. 73, no. 3, pp. 503-511, 2001.

[31] T. Y. Moustafa, Synthesis and characterization of some new phthalocyanines for potential industrial applications [Ph.D. thesis], University of Tübingen, Tübingen, Germany, 2004.

[32] M. Ebadi, C. Alexiou, and A. B. P. Lever, "The reduction of oxygen and hydrogen peroxide on dinuclear ruthenium phthalocyanine electrocatalytic surfaces," Canadian Journal of Chemistry, vol. 79, no. 5-6, pp. 992-1001, 2001.

[33] N. G. Connelly and W. E. Geiger, "Chemical redox agents for organometallic chemistry," Chemical Reviews, vol. 96, no. 2, pp. 877-910, 1996.

[34] K. Dürr and M. Hanack, "Synthesis and properties of tetrakis(trimethylsilyl)phthalocyaninatoruthenium(II)," Journal of Porphyrins and Phthalocyanines, vol. 3, no. 3, pp. 224-229, 1999. 

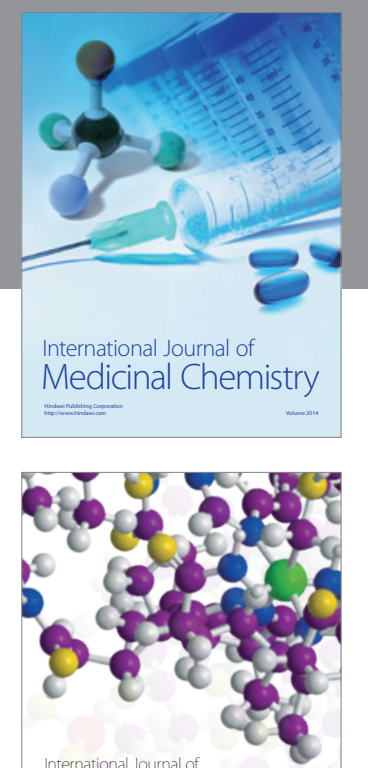

\section{Carbohydrate} Chemistry

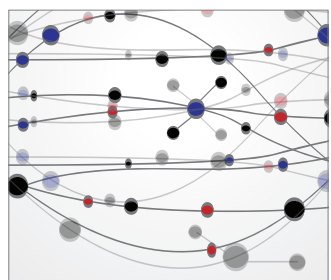

The Scientific World Journal
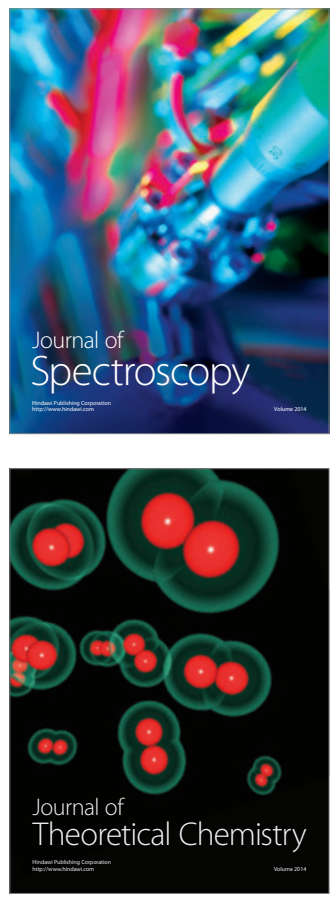
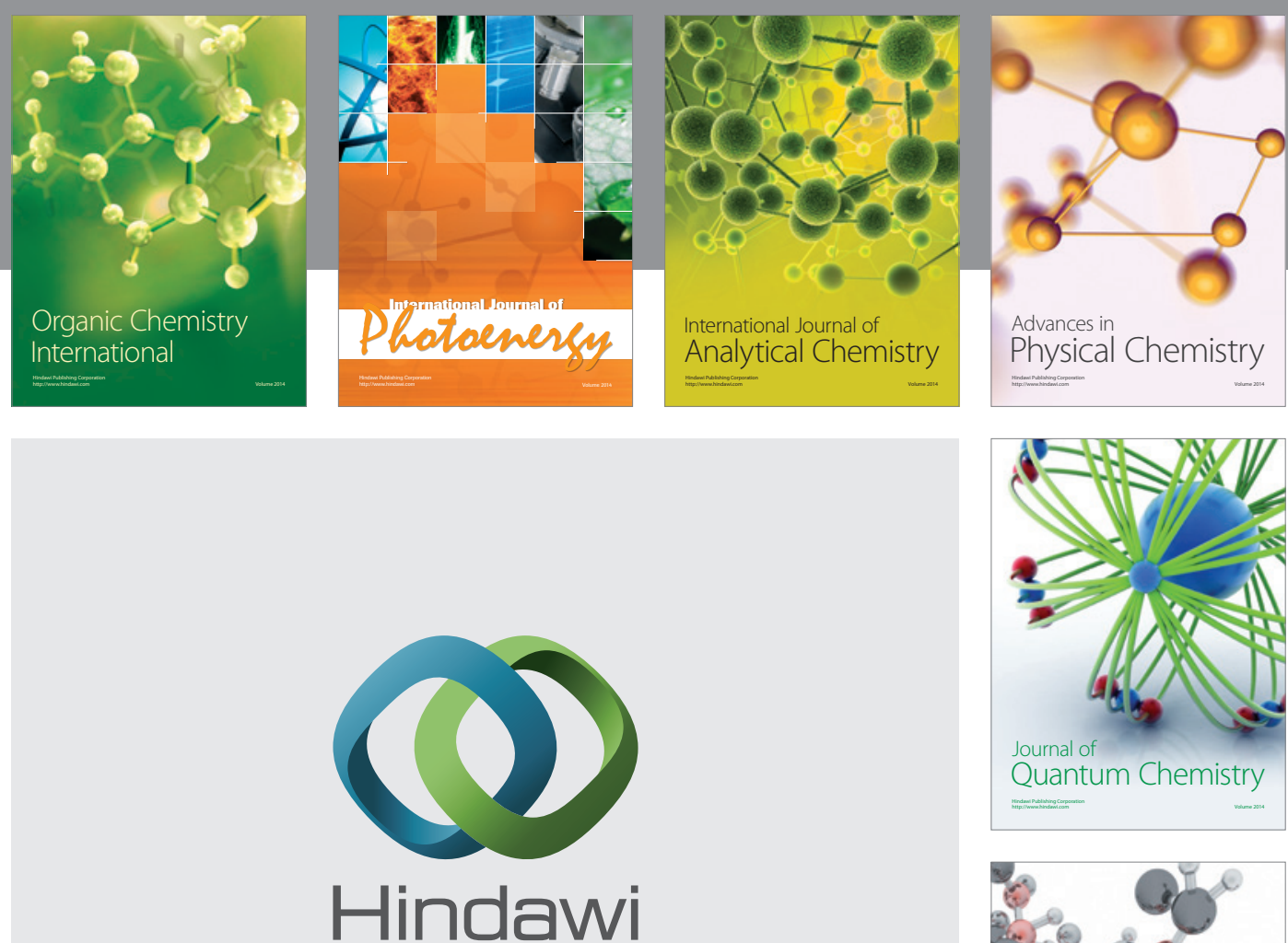

Submit your manuscripts at

http://www.hindawi.com

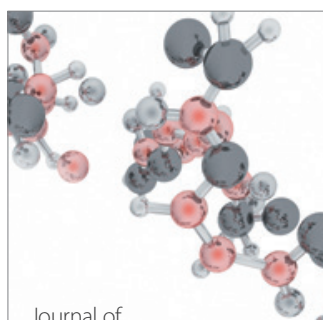

Analytical Methods

in Chemistry

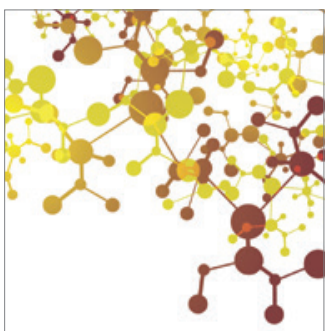

Journal of

Applied Chemistry

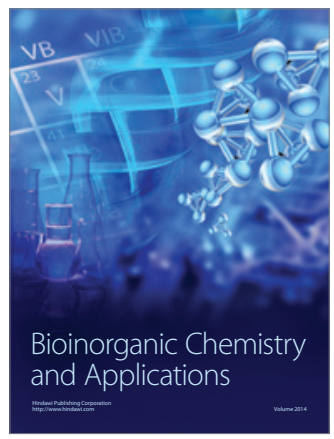

Inorganic Chemistry
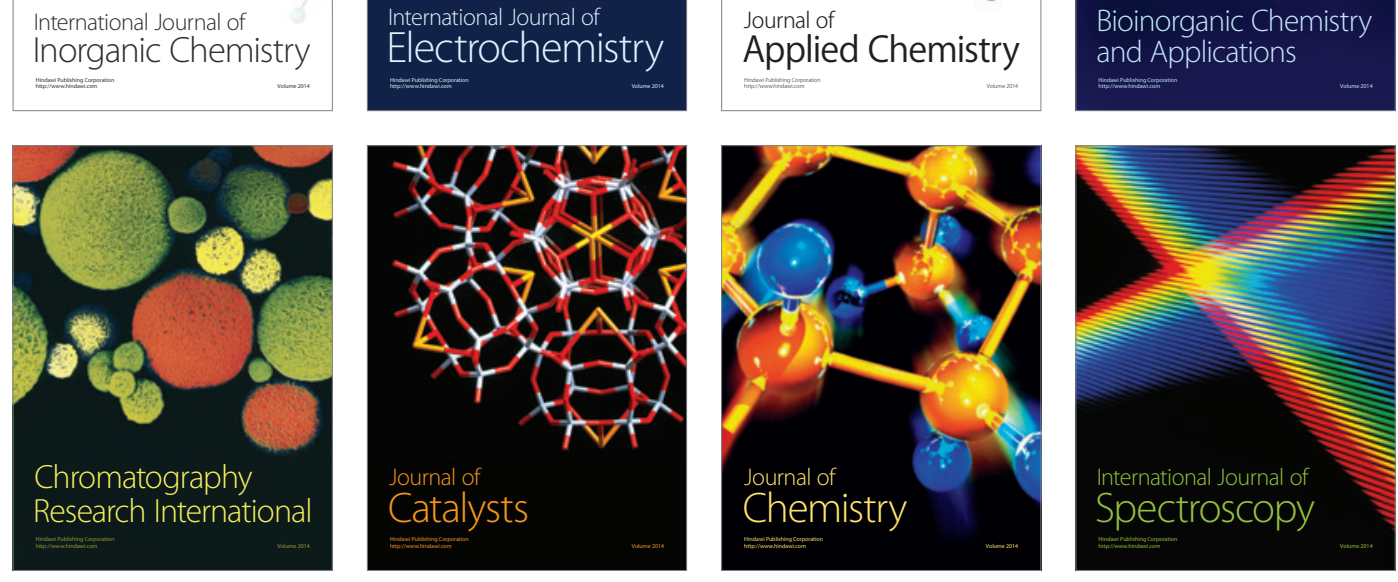